\title{
A massive pulmonary thromboembolism after pulmonary endarterectomy: A case report
}

\author{
Elif YILMAZEL UÇAR ${ }^{\mathbf{1}}$ (ID) \\ Bilge DONKAR ${ }^{1}$ (ID) \\ Ömer ARAZ ${ }^{1}$ (ID) \\ Metin AKGÜN ${ }^{1}$ (ID)
}

\author{
${ }^{1}$ Department of Chest Diseases, Faculty of Medicine, Atatürk University, \\ Erzurum, Turkey \\ ${ }^{1}$ Atatürk Üniversitesi Tıp Fakültesi, Göğüs Hastalıkları Anabilim Dalı, \\ Erzurum, Türkiye
}

Cite this article as: Yılmazel Uçar E, Donkar B, Araz Ö, Akgün M. A massive pulmonary thromboembolism after pulmonary endarterectomy: A case report. Tuberk Toraks 2020;68(1):76-79.

\section{Yazışma Adresi (Address for Correspondence)}

Dr. Elif YILMAZEL UÇAR

Atatürk Üniversitesi Tıp Fakültesi,

Göğüs Hastalıkları Anabilim Dalı, ERZURUM - TÜRKIYE

e-mail: eucar1979@yahoo.com

CCopyright 2020 by Tuberculosis and Thorax.

Available on-line at www.tuberktoraks.org.com

\begin{abstract}
A massive pulmonary thromboembolism after pulmonary endarterectomy: A case report

Pulmonary endarterectomy is a first choice treatment for chronic thromboembolic pulmonary hypertension which may be a complication of pulmonary thromembolism. Here, we present a 70-year-old female who admitted to our clinic with acute massive pulmonary thromboembolism after a pumonary endarterectomy operation because of non-compliance to anticoagulation treatment.
\end{abstract}

Key words: Pulmonary endarterectomy; massive pulmonary embolism; anticoagulation

ÖZ

Pulmoner endarterektomi sonrası masif pulmoner emboli: Olgu sunumu

Pulmoner endarterektomi, pulmoner embolinin bir komplikasyonu olabilen kronik tromboembolik pulmoner hipertansiyon için birincil seçenektir. Burada, kliniğimize pulmoner endarterektomi sonrası antikoagülan uyumsuzluğu nedeniyle masif pulmoner emboli ile başvuran, 70 yaşında bir kadın hastamızı sunduk.

Anahtar kelimeler: Pulmoner endarterektomi; masif pulmoner emboli; antikoagülasyon 


\section{INTRODUCTION}

Massive (high-risk) pulmonary thromboembolism (PTE) is a life-threatening disease. These patients account for less than $5 \%$ of acute PTE cases (1). Early hospital mortality in massive PTE cases varies between $25-65 \%$ (2).

Chronic thromboembolic pulmonary hypertension $(\mathrm{CTEPH})$ may be a complication of PTE. Pulmonary endarterectomy (PEA) is the first choice treatment for CTEPH (3-5). PEA is a technically difficult and long operation. In this operation, organized thrombus attached to the vessel intima is removed. After this operation, pulmonary vascular endothelial dysfunction develops and increased thrombomodulin causes abnormal hemostasis (6). Therefore, lifetime anticoagulation is required after the operation.

Here, we present a case who admitted to our clinic with acute massive pulmonary thromboembolism after a pumonary endarterectomy operation. The patients written informed consent was obtained.

\section{CASE REPORT}

A 70-year-old female was directed our clinic with the suspicion of chronic thromboembolic pulmonary hypertension. She was on anticoagulant treatment for six months. She was a housewife and admitted with progressively worsening shortness of breath for five years. She had history of COPD and treated with inhaler broncodilator therapy. But, pulmonary function test was normal. Physical examination caught out blood pressure $110 / 70 \mathrm{mmHg}$, pulse rate 115 beats/minute, respiratory rate 26 breaths/minute, jug- ular venous distention, and pitting edema in both lower extremities. Artery blood gas analysis (room air) elicited $\mathrm{pH}$ 7.47, $\mathrm{PCO}_{2} 23 \mathrm{mmHg}, \mathrm{PO}_{2} 67$ $\mathrm{mmHg}$, and $\mathrm{O}_{2}$ saturation $92 \%$. There were sinus tachycardia, right axis deviation, and right ventricle hypertrophy in electrocardiogram. Transthoracic echocardiography (TTE) exposed enlarged right chambers with right overload and severe tricuspid regurgitation with severe pulmonary hypertension PAB: $85 \mathrm{mmHg}$ There was eccentric filling defect eccentric in the central and both main pulmonary arteries with segmental and subsegmental pulmonary artery branches in thorax computed tomography (CT) angiography and the diameter of the pulmonary truncus increased by $43 \mathrm{~mm}$ (Figure 1). Ventilation perfusion scintigraphy imaging revealed perfusion mismatch with normal ventilation.

Right cardiac cathaterization was performed. The mean pulmonary artery pressure was $45 \mathrm{mmHg}$. The patient evaluated as CTEPH was directed to cardiovascular surgery for PEA (Figure 2).

There were no complications in the early postoperative follow-up of the patient. Control echocardiography was normal. Three months after pulmonary endarterectomy, she admitted to the emergency department with chest pain and respiratory distress complaint. Physical examination findings were blood pressure $90 / 50 \mathrm{mmHg}$, pulse rate 120 beats/minute, respiratory rate 30 breaths/minute. Blood tests revealed D-dimer 357 ng/mL, NT-pro BNP 5375 pg/ $\mathrm{mL}$. Artery blood gas analysis (room air) elicited $\mathrm{pH}$ 7.34, $\mathrm{PCO}_{2} 24 \mathrm{mmHg}, \mathrm{PO}_{2} 66 \mathrm{mmHg}$, lactic asit:
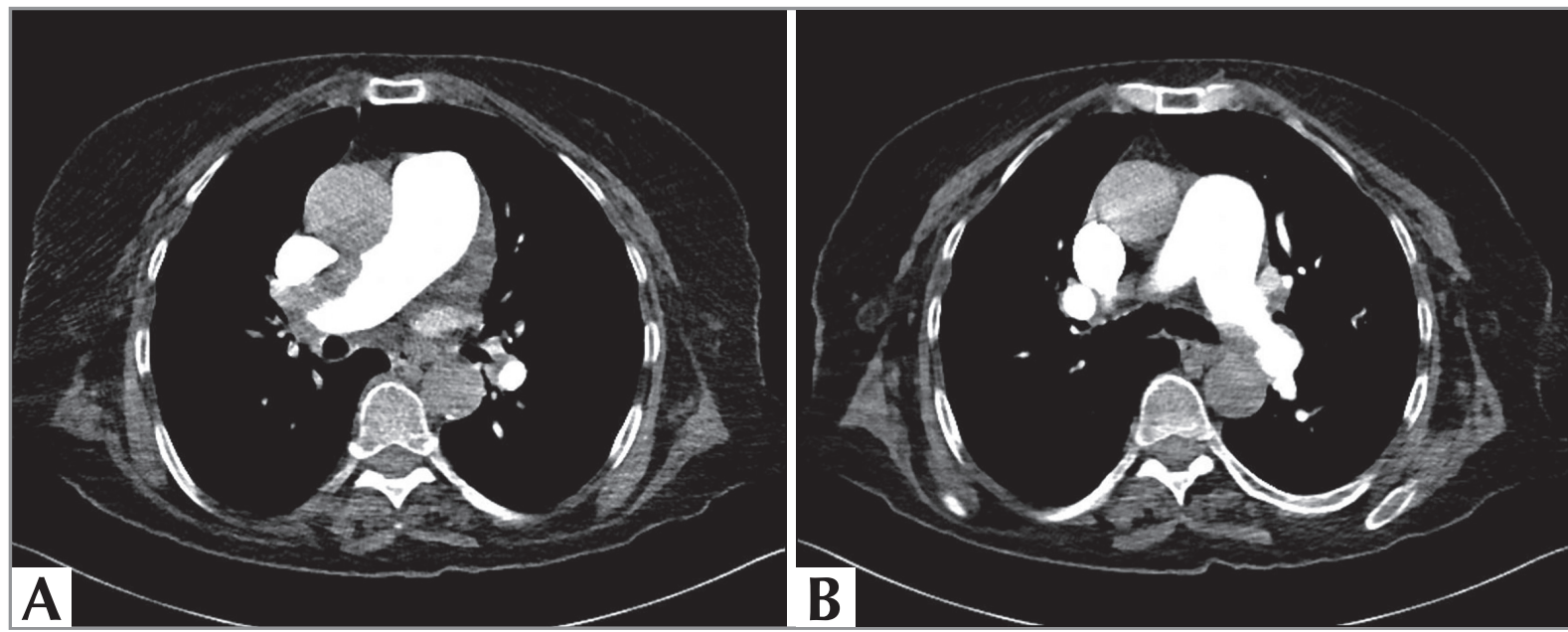

Figure 1. Control thorax computed tomography angiography pulmonary artery sections. 


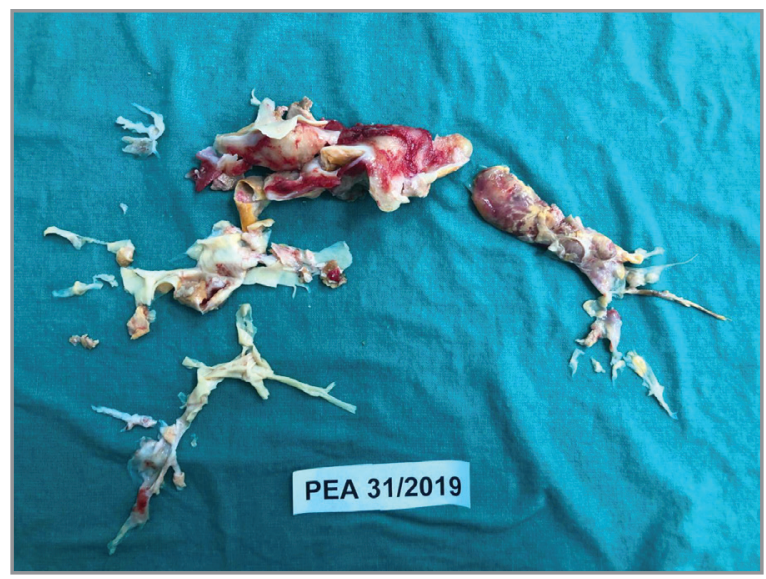

Figure 2. Post-operative pulmonary endarterectomy material organized thrombus.

5.7 and $\mathrm{O}_{2}$ saturation $89 \%$. Thorax CT revealed the diameter of the pulmonary truncus was dilated with $45 \mathrm{~mm}$. Both main pulmonary artery segmental, subsegmental pulmonary artery branches showed extremely progressive filling defects according to previous CT angiography images (Figure 3 ).

TTE revealed enlarged right chambers with right overload and severe tricuspid regurgitation with severe pulmonary hypertension. When the patient's post-operative treatment was questioned, she ended up using anticoagulant therapy for two weeks. She was admitted to intensive care service with the diagnosis of acute PTE. Thrombolytic therapy was held with 50 mg alteplase due to the absence of stable hemodynamics of the patient. Symptoms in the follow up and the height of lactic acid was declined. On the fourth day of follow-up, sudden cardiac arrest and death evolved.

\section{DISCUSSION}

We aimed to emphasize the importance of anticoagulant use in this case who presented with massive pulmonary thromboembolism clinic because she did not use anticoagulant after PEA.

Massive PTE is a life-threatening disease. Early hospiral mortality may reach $65 \%$ (2). Systemic thrombolytic therapy is the first choice for patients with massive PTE (7). The active resolution of thrombus via thrombolytic agents improves rapidly pulmonary perfusion, hemodynamic defect, gas exchange and right ventricular dysfunction. Currently, the most widely using agent is alteplase. In our case, $50 \mathrm{mg}$ alteplase was administered and the patient's hemodynamics and oxygenation improved. However, the patient died due to sudden cardiac arrest on the $4^{\text {th }}$ day after treatment.

PEA is the first choice treatment for CTEPH (3-5). It is a technically difficult and long operation. After this operation, lifelong anticoagulation is substantial because of pulmonary vascular endothelial dysfunction and increased thrombomodulin causes abnormal hemostasis (6). In our case, since she did not continue anticoagulant use after the operation, she was admitted to a more aggressive clinic.

In conclusion, we want to share this case to emphasize the importance of anticoagulant use after pulmonary endarterectomy.

\section{CONFLICT of INTEREST}

The authors reported no conflict of interest related to this article.

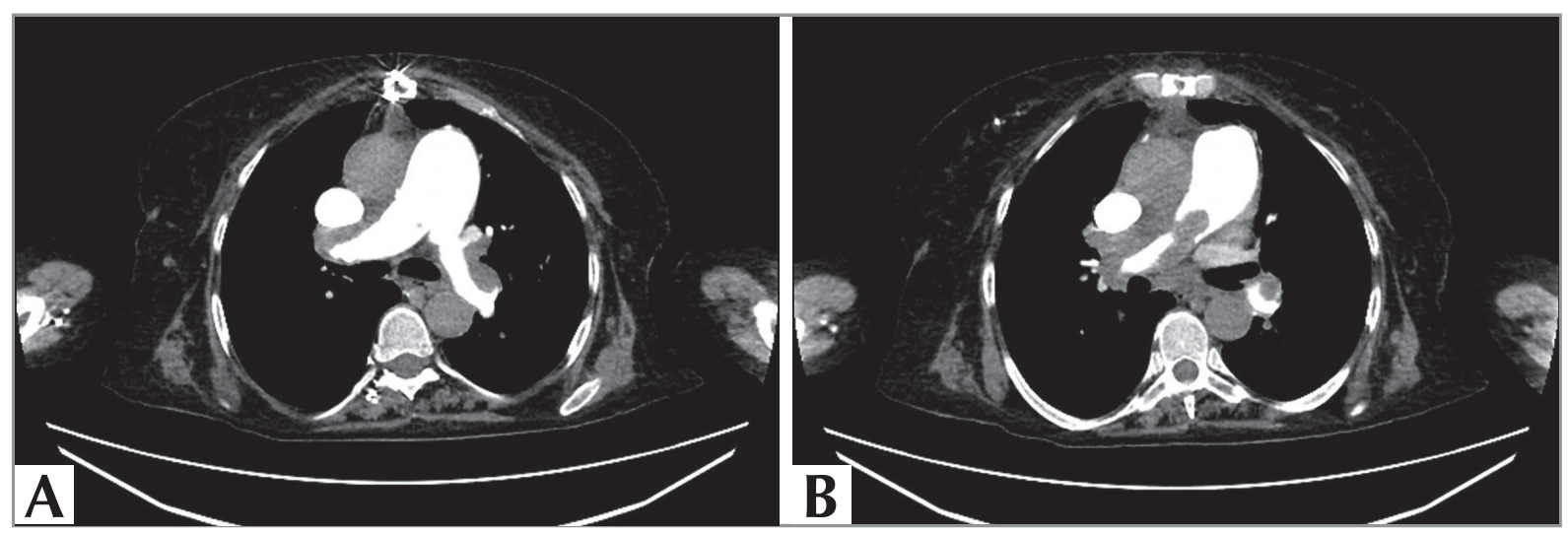

Figure 3. Thorax computed tomography angiography pulmonary artery sections in the postoperative third month emergency application. 


\section{REFERENCES}

1. Stein PD, Matta F. Thrombolytic therapy in unstable patients with acute pulmonary embolism: saves lives but underused. Am J Med 2012;125:465-70.

2. Jaff MR, McMurtry MS, Archer SL, Cushman M, Goldenberg $N$, Goldhaber SZ, et al. Management of massive and submassive pulmonary embolism, iliofemoral deep vein thrombosis, and chronic thromboembolic pulmonary hypertension: a scientific statement from the American Heart Association. Circulation 2011;123(16):1788-830.

3. Madani M, Mayer E, Fadel E, Jenkins DP. Pulmonary endarterectomy. Patient selection, technical challenges, and outcomes. Ann Am Thorac Soc 2016;13:S240-7.

4. Machuca $T$, de Perrot M. When to refer a patient with chronic thromboembolic pulmonary hypertension for pulmonary endarterectomy. Can J Cardiol 2015;31:509-14.
5. Albani S, Biondi F, Stolfo D, Lo Giudice F, Sinagra G. Chronic thromboembolic pulmonary hypertension (CTEPH): what do we know about it? A comprehensive review of the literature. I Cardiovasc Med (Hagerstown) 2019;20:159-68.

6. Sakamaki $F$, Kyotani $S$, Nagaya $N$, Sato $N$, Oya $H$, Nakanishi N. Increase in thrombomodulin concentrations after pulmonary thromboendarterectomy in chronic thromboembolic pulmonary hypertension. Chest 2003; 124:1305-11.

7. Yilmazel Ucar E. Update on thrombolytic therapy in acute pulmonary thromboembolism. Eurasian I Med 2019;51(2):185-9. 